\title{
Development of an Automatic Measurement Method for CD8 and PD-1 Positive T Cells Using Image Analysis Software
}

\author{
HARUO MIYATA $^{1 *}$, YASUTO AKIYAMA ${ }^{1 *}$, AKIRA IIZUKA ${ }^{1}$, RYOTA KONDOU $^{1}$, CHIE MAEDA $^{1}$, \\ AKARI KANEMATSU ${ }^{1}$, KYOKO WATANABE ${ }^{1}$, TADASHI ASHIZAWA ${ }^{1}$, TAKESHI NAGASHIMA ${ }^{2,3}$, \\ KENICHI URAKAMI ${ }^{2}$, KEIICHI OHSHIMA ${ }^{4}$, TAKUYA KAWATA ${ }^{5}$, KOJI MURAMATSU ${ }^{5}$, AKIO SHIOMI ${ }^{6}$, \\ MASANORI TERASHIMA ${ }^{7}$, TAKASHI SUGINO ${ }^{5}$, AKIFUMI NOTSU ${ }^{8}$, KEITA MORI $^{8}$ and KEN YAMAGUCHI $^{9}$ \\ ${ }^{1}$ Immunotherapy Division, Shizuoka Cancer Center Research Institute, Shizuoka, Japan; \\ ${ }^{2}$ Cancer Diagnostics Research Division, Shizuoka Cancer Center Research Institute, Shizuoka, Japan; \\ ${ }^{3}$ SRL, Tokyo, Japan; \\ ${ }^{4}$ Medical Genetics Division, Shizuoka Cancer Center Research Institute, Shizuoka, Japan; \\ ${ }^{5}$ Division of Pathology, Shizuoka Cancer Center Hospital, Shizuoka, Japan; \\ ${ }^{6}$ Division of Colon and Rectal Surgery, Shizuoka Cancer Center Hospital, Shizuoka, Japan; \\ ${ }^{7}$ Division of Gastric Surgery, Shizuoka Cancer Center Hospital, Shizuoka, Japan; \\ ${ }^{8}$ Clinical Trial Coordination Office, Shizuoka Cancer Center Hospital, Shizuoka, Japan; \\ ${ }^{9}$ Shizuoka Cancer Center, Shizuoka, Japan
}

\begin{abstract}
Background/Aim: With the progress in cancer immunotherapy using immune checkpoint blockade (ICB) therapy, histological observations of tumor-infiltrating lymphocyte (TIL) status are needed to evaluate the antitumor effect of ICB using imaging analysis software. Materials and Methods: Formalin-fixed paraffin-embedded sections obtained from colorectal cancer and gastric cancer patients with more than 500 single nucleotide variants were stained with antiCD8 and anti-PD-1 antibodies. Based on our own algorithm and imaging analysis software, an automatic TIL measurement method was established and compared to the manual counting methods. Results: In the $C D 8^{+} T$ cell number measurement, there was a good correlation ( $r=0.738$ by Pearson test) between the manual and automated counting methods. However, in the $P D-1^{+} T$ cell measurement, there was a large difference in TIL numbers in both groups. After adjustment of
\end{abstract}

This article is freely accessible online.

*These Authors contributed equally to this work.

Correspondence to: Yasuto Akiyama, MD, Immunotherapy Division, Shizuoka Cancer Center Research Institute, 1007 Shimonagakubo, Nagaizumi-cho, Sunto-gun, Shizuoka 411-8777, Japan. Tel: +81 559895222 (Ext. 5330), Fax: +81 559896085 , e-mail: y.akiyama@scchr.jp

Key Words: Tumor microenvironment (TME), tumor-infiltrating lymphocytes (TILs), automatic measurement, imaging analysis software, digital pathology, project HOPE. the parameter settings, the correlation between the manual and automated methods in the PD-1 $1^{+} T$ cell measurements improved ( $r=0.668$ by Pearson test). Conclusion: An imaging software-based automatic measurement could be a simple and useful tool for evaluating the therapeutic effect of cancer immunotherapies in terms of TIL status.

Since the clinical applications of immune checkpoint blockade (ICB) therapy have had great success in various cancer patients, the number of clinical trials focused on novel therapies, including the combination of ICB with other targeting agents, have been increasing $(1,2)$. The greater the number of ICBbased clinical trials, the more difficult visual inspections by trained pathologists have become for the evaluation of immune effects by ICB, such as tumor-infiltrating lymphocyte (TIL) measurement and programmed death-ligand 1 (PD-L1) staining.

In fact, many pathologists have intensively studied methods to enumerate TIL numbers accurately and efficiently and demonstrated that a well-functioning immune-scoring system could contribute to determine the TIL status of tumors (3-6). However, manual visual inspections are time-consuming and require manual labor; therefore, an efficient and user-friendly automatic immunohistochemistry (IHC) imaging analysis system is urgently needed. Specifically, since the development of whole slide scanners that can generate ultralarge 2D images in the field of digital pathology, open source bioimage analysis software has been developed, such as ImageJ, Fiji, Icy, and CellProfiler (7-10). However, in terms of high variability and limited reproducibility, it has been difficult for computational researchers to develop state-of-the-art imaging software 
available worldwide. Recently, to solve these problems novel comprehensive opensource software, QuPath (11) has been developed for analyzing a substantial amount of whole slide imaging data mainly in Western countries (12). These developed digital image-analysis software programs are considered to improve the discrepancy in both intra- and interobserver visual analyses in terms of accuracy and reproducibility (13).

In the present study, we developed a novel automatic IHC TIL-measurement algorithm based on WinROOF imaging software (Mitani Corporation, Tokyo, Japan) and different approaches from QuPath software that previously used and compared $\mathrm{CD}^{+}$and $\mathrm{PD}-1^{+} \mathrm{T}$ cell numbers in formalin-fixed paraffin-embedded (FFPE) specimens in terms of visual and automatic measurements.

\section{Materials and Methods}

Patient characteristics and clinical specimen. Shizuoka Cancer Center launched Project HOPE in 2014 using multiomics analyses including whole exome sequencing (WES) and gene expression profiling (GEP). Ethical approval for the HOPE study was obtained from the Institutional Review Board of Shizuoka Cancer Center (Authorization Number: 25-33). Fifty-two clinical specimens derived from HOPE-registered hypermutator tumors with more than 500 single nucleotide variants (SNVs), which consisted of 26 gastric cancers and 26 colorectal cancers, were obtained and FFPE sections were made and used for IHC analysis.

Immunohistochemistry. For TIL staining, anti-CD8 and antiprogrammed death (PD)-1 antibodies (Thermo Fisher Scientific, Waltham, MA, USA) were purchased and used for immunohistochemistry analysis as primary antibodies.

Slides were incubated with a horseradish peroxidase (HRP)conjugated anti-mouse secondary antibody, and after washing, they were incubated with 3,39-diaminobenzidine tetrahydrochloride (DAB) (Sigma-Aldrich Co., St. Louis, MO, USA) until color development. The slides were then counterstained with hematoxylin, and observed under a light microscope (IX71N-23TFL/DIC, Olympus, Tokyo, Japan) equipped with a digital camera (DP70SET-B, Olympus) and image analysis software (WinROOF, Mitani Corporation). In each section stained with the various antibodies, 10 visual images at high-magnification (200X) were captured and analyzed using WinROOF image-analysis software. The manual counting of stained TILs was performed two times by the reviewer according to the semiquantitative estimation of the density score (14) and the mean value was determined.

CD8 and PD-1 gene expression analysis using quantitative PCR. Real-time PCR analysis of CD8 and PD1 genes using a QuantStudio 12K Flex (Applied Biosystems, Foster City, CA, USA) was performed as described previously (15). Total RNA was isolated from the FFPE specimens of 15 colorectal cancers and 15 gastric cancers with hypermutations (more than $500 \mathrm{SNVs}$ ). Specific PCR primers for $C D 8 B, P D C D 1$, and $G A P D H$ were used. The correlation of manual count number or automatic count number of $\mathrm{CD}^{+}$and PD-1+ cells with mRNA gene expression level, shown as delta-delta $\mathrm{Ct}$ values in a real time PCR, was investigated using a Pearson correlation test.
Development of an automated measurement process using an established WinROOF-based algorithm. A flow chart demonstrating the manual and automatic $\mathrm{T}$ cell measurement processes is shown in Figure 1. Five visual images out of 10 captured images were selected at random. The reviewer performed manual counting of $\mathrm{CD}^{+}$or PD-1+ $\mathrm{T}$ cell numbers two times in each section. After counting, the mean positively stained cell number per visual field was determined. Meanwhile, regarding the automatic measurement of positively stained cells, the process is shown in Figure 2. From the automatic setting in $\mathrm{CD} 8+\mathrm{T}$ cell determination, the setting of automatic PD-1+ $\mathrm{T}$ cell measurement was adjusted to the manual measurement level of PD-1+ $\mathrm{T}$ cell number.

Color conversion from RGB to HSL (hue, saturation and lightness). In brief, after identifying the cancer areas of the images, DAB-stained reddish color was converted from RGB to HSL. Joblove et al. defined another color space or coordinate system other than RGB for color expression or manipulation, and introduced the HSL color space for hue, saturation, and lightness (16). Specifically, the maximum (MAX) value and the minimum value (MIN) of RGB were identified. In the cases of different MAX values, different $H$ values were calculated and the $\mathrm{S}$ and $\mathrm{L}$ values were determined as follows:

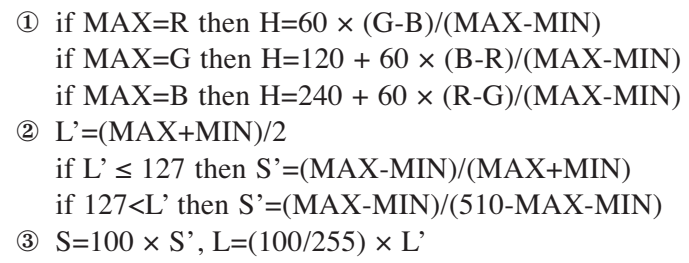

Cell radius. The diameter of T cells was approximately $12 \mu \mathrm{m}$, and considering that the cleaved surface of the cell was smaller than that of the large circle, the diffusion of the staining range, 5 to $15 \mu \mathrm{m}$, was set as the diameter range.

Roundness. To separate the deformed dyeing range, assuming that it is elliptical, the circularity was calculated as follows (17):

$(\mathrm{x} / \mathrm{a})^{2}+(\mathrm{y} / \mathrm{b})^{2}=1$ (Elliptical equation)

Where $\mathrm{a}$ is the major axis radius and $\mathrm{b}$ is the minor axis radius. When $a / b$ exceeds a certain range, it is judged as multiple.

Statistical analysis. A correlation analysis of the CD8 ${ }^{+}$and PD-1+ cell numbers between manual and automatic measurements from IHC specimens of 52 hypermutator tumors with more than 500 SNVs was performed by the Pearson correlation test using EZR software (18) and Microsoft Excel. Values of $p<0.05$ were considered statistically significant.

\section{Results}

Comparison between manual counting and automatic counting in $\mathrm{CD}^{+} \mathrm{T}$ cell measurement. The $\mathrm{CD}^{+} \mathrm{T}$ cell numbers between manual and automatic counting were compared. Automatic measurement was performed at the first parameter setting adjusted to the manual counting number of $\mathrm{CD}^{+} \mathrm{T}$ cells. There were significant correlations 


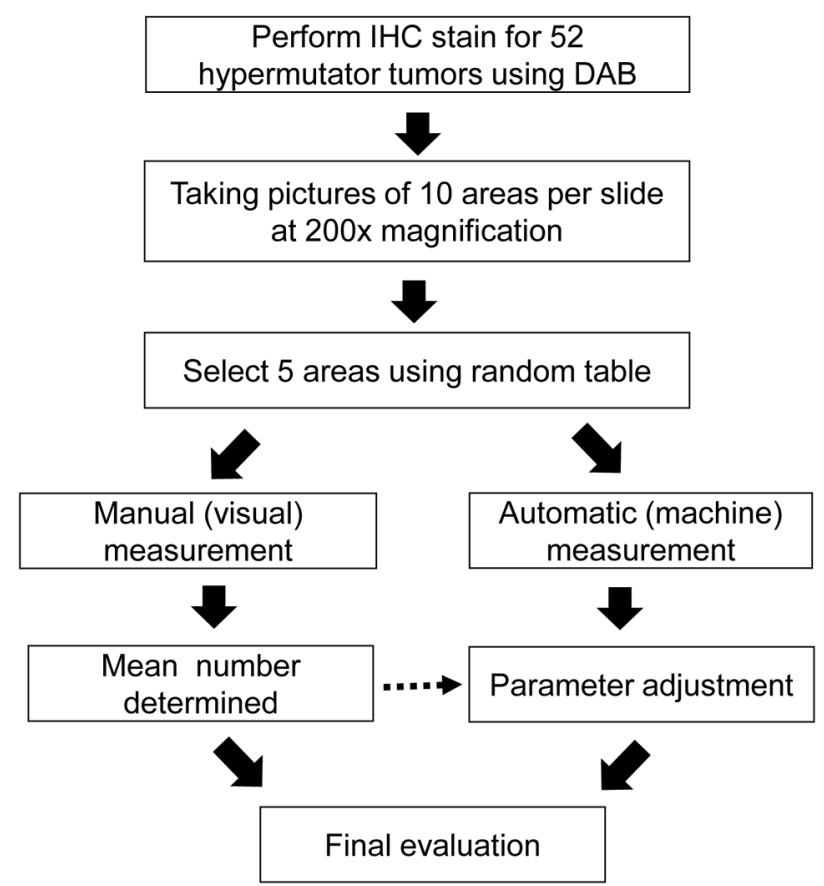

Figure 1. Schematic of the manual and automatic image analysis procedures. Manual measurement was performed two times for each section, and the mean value was determined. Automatic measurement was performed by our own specific algorithm based on WinROOFbased imaging analysis.

between manual and automatic counting numbers in gastric cancer and colorectal cancer groups (Figure 3A and B).

Accordance and discrepancy between manual and automatic counting numbers at the first parameter setting. The $\mathrm{CD}^{+}$ $\mathrm{T}$ cell number per visual field obtained from the automatic measurement was similar to that obtained from manual counting, as shown in Figure 4A. However, the automatically counted PD $-1^{+} \mathrm{T}$ cell number showed a great difference from the manual counting at the first parameter setting. Therefore, the parameter setting was readjusted to the manual PD- $1^{+} \mathrm{T}$ cell number condition, referred to as the second parameter setting (Figure 4B).

Improvement in the correlation between manual counting and automatic counting in PD-1 $1^{+}$T cell measurement after readjustment of the parameter setting. The $\mathrm{PD}-1^{+} \mathrm{T}$ cell numbers between manual and automatic counting were compared. Automatic measurement was performed at the second parameter setting adjusted to the manual counting number of $\mathrm{PD}-1^{+} \mathrm{T}$ cells. There was a significant improvement in the correlations between manual and automatic counting numbers in the gastric cancer and colorectal cancer groups (Figure 5).

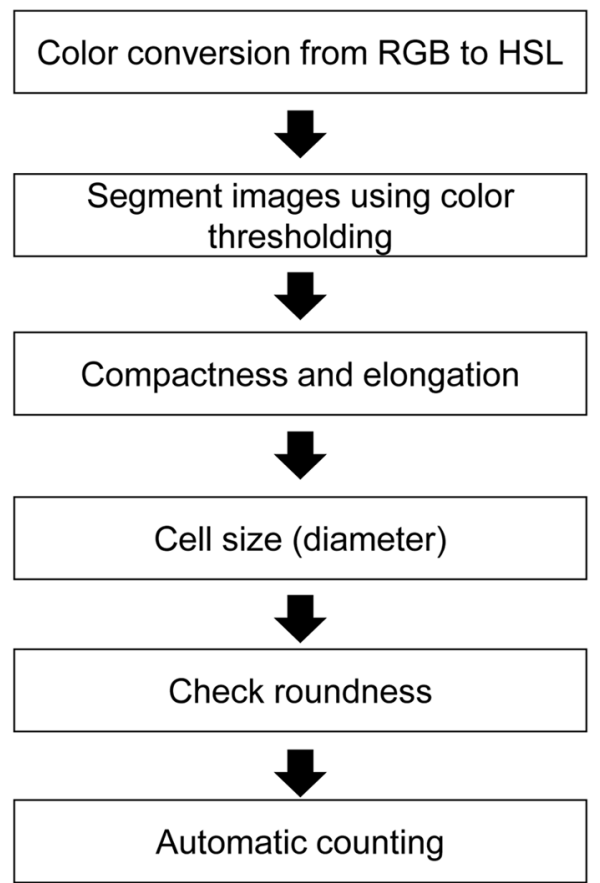

Figure 2. Schematic of the automatic measurement procedures based on our own specific algorithm. The process consists of color conversion, segmentation by color thresholding, compactness and elongation, cell size determination, checking roundness etc.

Significant correlation between manual counting and automatic counting in $C D 8^{+}$or $P D-1^{+}$T cell measurements of hypermutator tumors. The significant correlations between the manual and automatic counts of $\mathrm{CD}^{+}$or $\mathrm{PD}-1^{+} \mathrm{T}$ cells in all 52 hypermutator tumors are shown in Figure 6. Each automatic $\mathrm{T}$ cell measurement was performed at the first or second parameter setting. The coefficiency values were 0.738 (A: $\mathrm{CD}^{+}$cells) and $0.669\left(\mathrm{~B}: \mathrm{PD}-1^{+}\right.$cells).

Association of automatic or manual count numbers with mRNA gene expression levels. Regarding gastric cancers, CD8 gene expression was well-associated with both automatic and manually counted numbers; however, $P D-1$ gene expression had a greater association with manually counted numbers than with automatically counted numbers. Regarding colorectal cancers, neither the automatic count nor the manual count showed a significant association with $C D 8$ and $P D-1$ gene expression levels (Table I).

\section{Discussion}

With advances in cancer immunotherapy using ICB, many novel combination immunotherapies based on ICB and targeting therapeutics have been developed in various stages of 

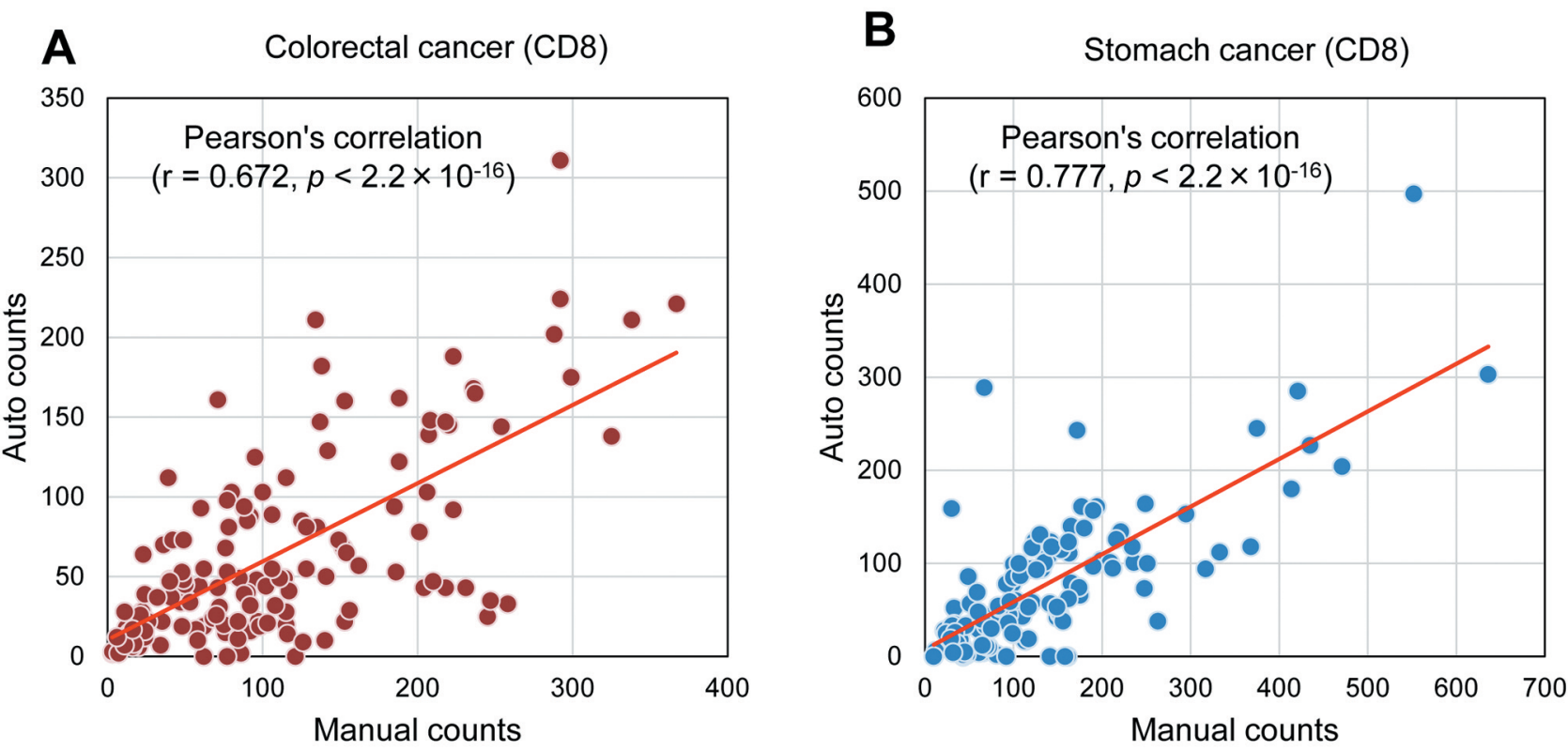

Figure 3. Comparison between manual counting and automatic counting in $C D 8^{+} T$ cell measurement. The CD8 ${ }^{+} T$ cell numbers between manual and automatic counting were compared. Automatic measurement was performed at the first parameter setting adjusted to the manual counting number of $C D 8^{+} T$ cells. (A) Colorectal cancers (red circles), (B) gastric cancers (blue circles). A correlation analysis was performed by the Pearson test. $* p<0.05$, statistically significant.

A
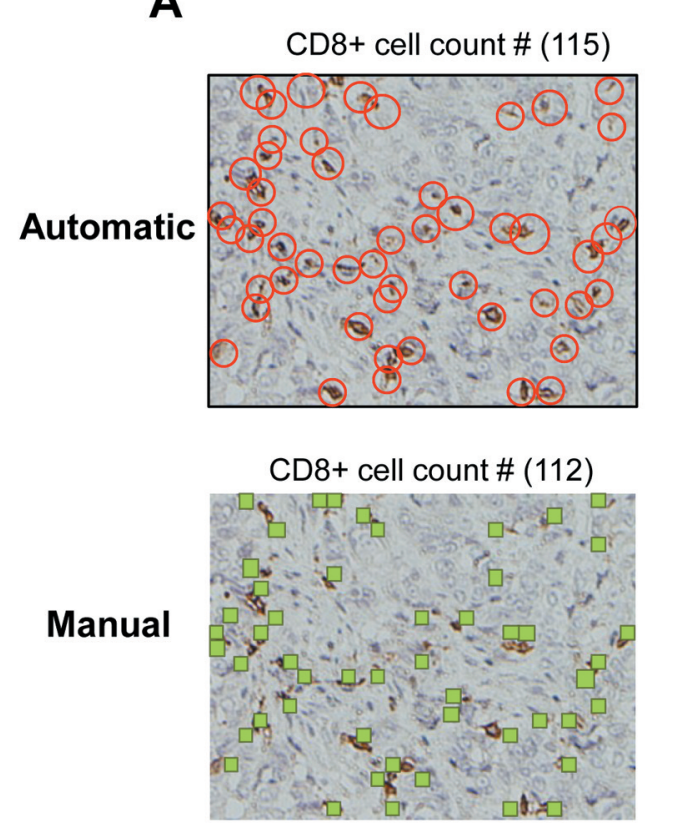

B

PD-1+ cell count \# (52)

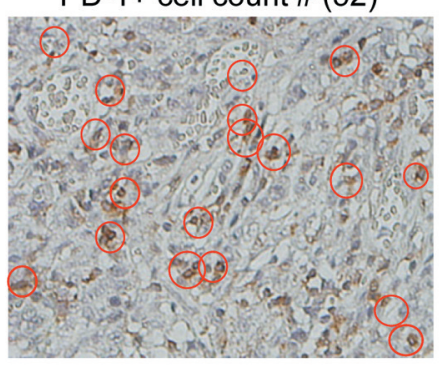

PD-1+ cell count \# (204)

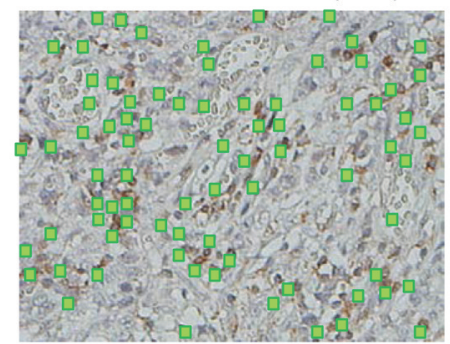

C

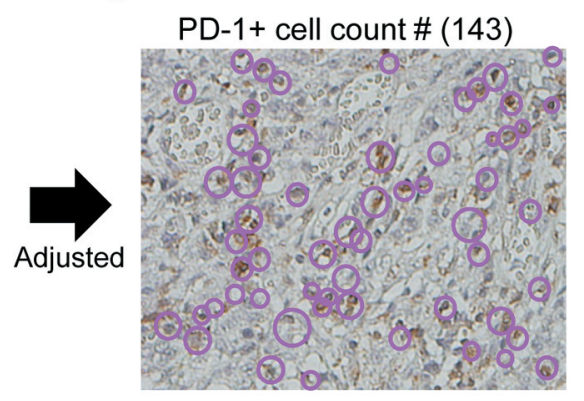

Figure 4. Representative colorectal cancer cases were used for the current staining of $C D 8^{+}$or $P D-1^{+} T$ cells. The image shown is a part of the whole image of a single visual field at 200x, and each counted number of $C D 8^{+}$or PD-1+ $T$ cells in the automatic and manual measurements shows the cell number of the whole visual field. The automatic measurement in images A and B is based on the first parameter setting, while the automatic measurement in image $C$ is based on the second parameter setting. SNV\# 10543 in A and 1965 in B. 

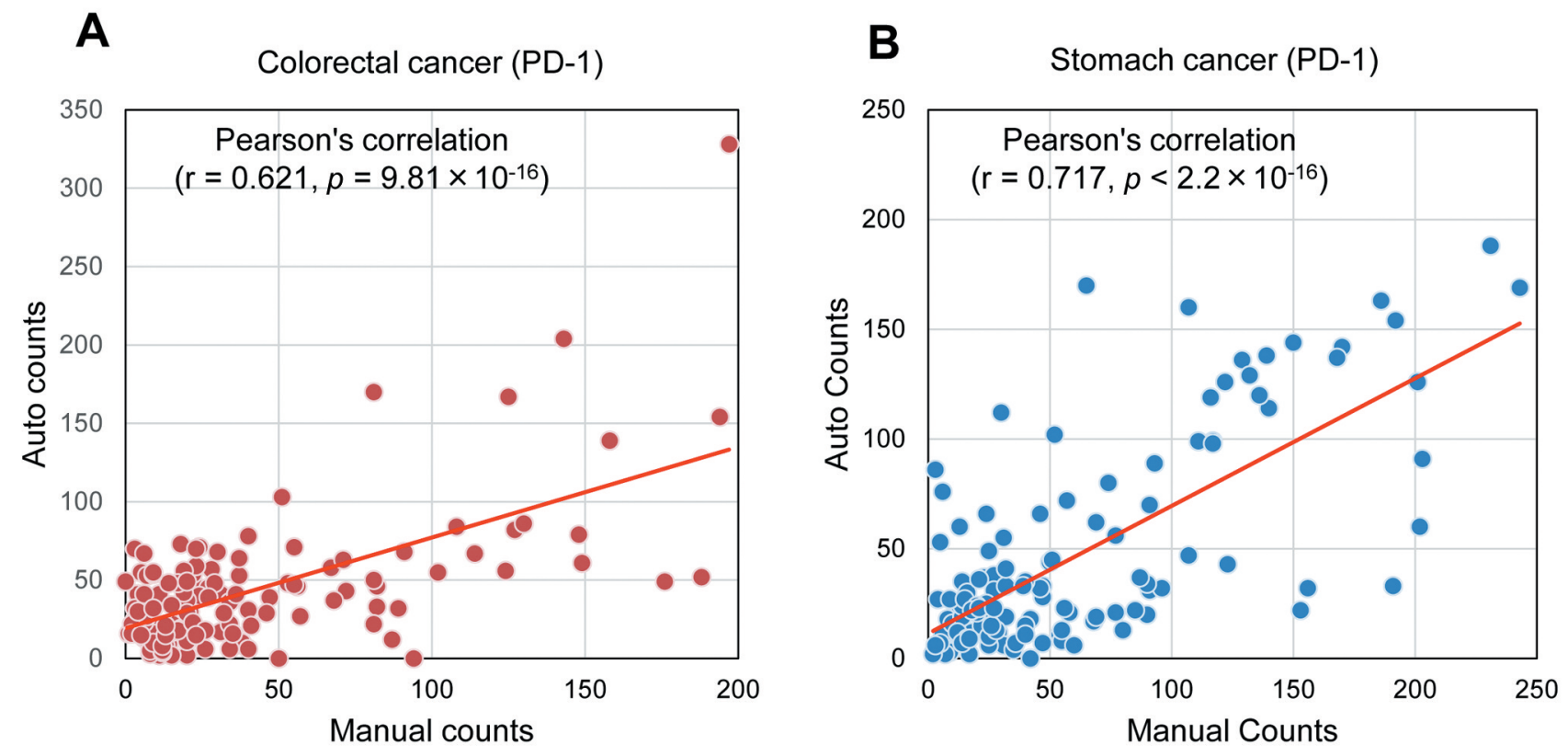

Figure 5. Comparison between the manual counting and automatic counting in PD- $1^{+}$T cell measurements. Automatic measurement was performed at the second parameter setting adjusted to the manual counting number of PD-1+ T cells. (A) Colorectal cancers (red circles), (B) gastric cancers (blue circles). A correlation analysis was performed by the Pearson test. ${ }^{*} p<0.05$, statistically significant.
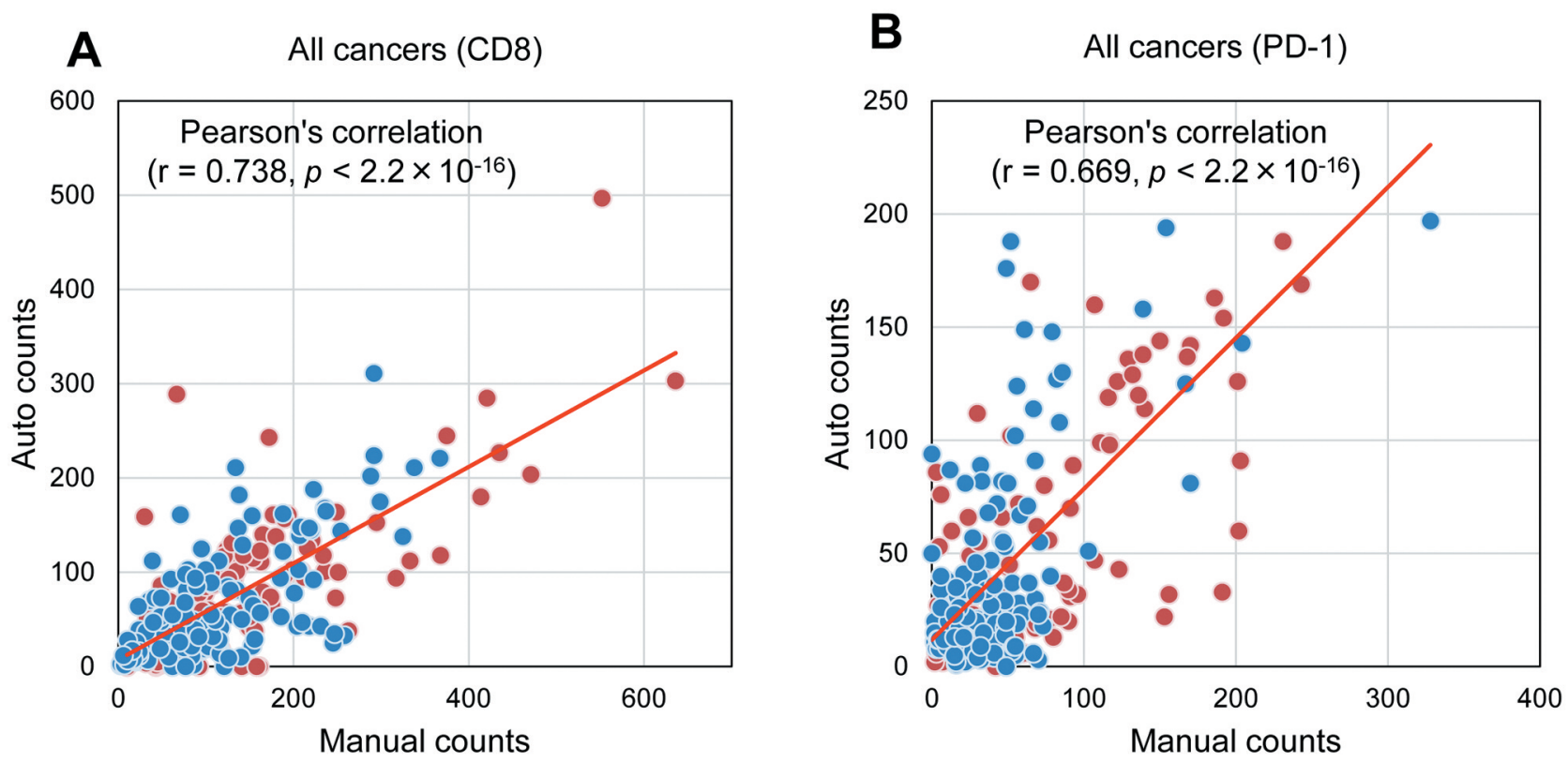

Figure 6. The significant correlation between the manual counting and automatic counting in $C D 8^{+}$or $P D-1^{+} T$ cell measurements of hypermutator tumors. Significant correlations between manual and automatic counts of $C D 8^{+}(A)$ or $P D-1^{+} T$ cells $(B)$ in 52 hypermutator tumors are shown. Each automatic $T$ cell measurement was performed at the first $(A)$ or second $(B)$ parameter setting. Colorectal cancers are represented by red circles, and gastric cancers are represented by blue circles. A correlation analysis was performed by the Pearson test. ${ }^{*} p<0.05$, statistically significant. 
Table I. Association of auto- or manual count number with mRNA gene expression level.

\begin{tabular}{lcc}
\hline Groups & Auto-count $v s . \mathrm{qPCR}$ & Manual-count $v s$. qPCR \\
\hline Gastric cancer (CD8) & $\mathrm{r}=0.862\left(p<0.001^{*}\right)$ & $\mathrm{r}=0.790\left(p<0.001^{*}\right)$ \\
Colorectal cancer (CD8) & $\mathrm{r}=0.185(p=0.356)$ & $\mathrm{r}=0.142(p=0.480)$ \\
All cancers (CD8) & $\mathrm{r}=0.271(p=0.052)$ & $\mathrm{r}=0.226(p=0.056)$ \\
Gastric cancer (PD-1) & $\mathrm{r}=0.322(p=0.117)$ & $\mathrm{r}=0.747(p<0.001 *)$ \\
Colorectal cancer (PD-1) & $\mathrm{r}=-0.071(p=0.727)$ & $\mathrm{r}=-0.229(p=0.251)$ \\
All cancers (PD-1) & $\mathrm{r}=0.132(p=0.350)$ & $\mathrm{r}=0.630(p<0.001 *)$ \\
\hline
\end{tabular}

The correlation of manual count number or automatic count number of $\mathrm{CD} 8^{+}$and $\mathrm{PD}-1^{+}$cells with mRNA gene expression levels shown as delta Ct values in a real time PCR, was investigated using a Pearson correlation test. $* p<0.01$.

Table II. Imaging software-based automatic IHC measurement methods.

\begin{tabular}{|c|c|c|c|c|c|c|}
\hline Authors & Year & $\begin{array}{l}\text { Imaging system } \\
\text { (software) }\end{array}$ & Algorithms & $\begin{array}{l}\text { Target } \\
\text { markers }\end{array}$ & Descriptions & $\begin{array}{l}\text { Ref } \\
\text { No. }\end{array}$ \\
\hline Varghese et al. & 2014 & $\begin{array}{l}\text { The AxioVisionV4.6 } \\
\text { software } \\
\text { (Zeiss, Germany) }\end{array}$ & $\begin{array}{c}\text { IHC profiler: quantitative } \\
\text { scoring (https://sourceforge.net/ } \\
\text { projects/ihcprofiler/) }\end{array}$ & Various many & $\begin{array}{l}\text { Comparison study between } \\
\text { manual pathological analysis } \\
\text { and IHC Profiler resolved } \\
\text { in a match of } 88.6 \% \text { in } \\
\text { various cancers }\end{array}$ & [26] \\
\hline Wanram et al. & 2016 & $\begin{array}{l}\text { The Aperio product, } \\
\text { a combination } \\
\text { of the Genie }{ }^{\circledR} \\
\text { Histology Pattern } \\
\text { Recognition tool }\end{array}$ & $\begin{array}{l}\text { The Membrane Quantification } \\
\text { V9 cellular analysis tool }\end{array}$ & $\begin{array}{l}\text { HLA-class I } \\
\text { and tapasin }\end{array}$ & $\begin{array}{l}\text { Significant association } \\
\text { between conventional and } \\
\text { automated IHC evaluation } \\
\text { for MHC class I and } \\
\text { Tapasin was shown in } \\
96 \text { cervical cancers }\end{array}$ & {$[27]$} \\
\hline Mane et al. & 2017 & $\begin{array}{l}\text { Leica application } \\
\text { software version } \\
3.5 .0 \text { (Germany) }\end{array}$ & $\begin{array}{l}\text { Free open software } \\
\text { ImageJ (ACTREC, } \\
\text { Navi Mumbai, India) }\end{array}$ & Tenascin-C & $\begin{array}{l}\text { IHC can be quantified using } \\
\text { ImageJ analysis software in oral } \\
\text { precancerous tissues and OSCC }\end{array}$ & [28] \\
\hline $\begin{array}{l}\text { Fernandez- } \\
\text { Carrobles } \text { et al. }\end{array}$ & 2017 & $\begin{array}{c}\text { The Aperio ScanScope } \\
\text { XTscanner }\end{array}$ & $\begin{array}{l}\text { A combinantion of Macenko's } \\
\text { method, Reinhard's method } \\
\text { and Non-linear spline } \\
\text { mapping method }\end{array}$ & 12 biomarkers & $\begin{array}{l}\text { The tests carried out with } \\
8000 \text { bresat cancer TMA } \\
\text { images providedan average } \\
\text { of } 95.94 \% \text { accuracy }\end{array}$ & [29] \\
\hline Tewary et al. & 2017 & $\begin{array}{l}\text { Leica DMi1 microscope } \\
\text { (resolution } 1,048 \times 768 \\
\text { pixels) and Leica DM750 } \\
\text { microscope (resolution } \\
2,048 \times 1,536 \text { pixels) }\end{array}$ & $\begin{array}{l}\text { Machine leraning model } \\
\text { (random forest), } \\
\text { automated Allred } \\
\text { score generation }\end{array}$ & ER and PR & $\begin{array}{l}\text { Random forest shows the } \\
\text { best correlation with the } \\
\text { expert's score (Pearson's } \\
\text { correlation coefficient= } \\
0.9192 \text { ) in } 50 \text { bresat cancers }\end{array}$ & {$[30]$} \\
\hline Brown et al. & 2019 & $\begin{array}{l}\text { Developer XD } \\
\text { software (Definiens; } \\
\text { Munich, Germany) }\end{array}$ & $\begin{array}{l}\text { Segmentation of CTLA-4+ } \\
\text { cells was carried out } \\
\text { and then applying a } \\
\text { color deconvolution } \\
\text { to isolate the } \\
\text { purple-stained pixels }\end{array}$ & $\begin{array}{l}\text { CTLA-4, FoxP3, } \\
\text { CD4, CD8 }\end{array}$ & $\begin{array}{c}\text { Image analysis scoring } \\
\text { was highly comparable } \\
\text { with pathologist scoring } \\
\text { for CTLA-4 and } \\
\text { CTLA-4/FoxP3 assays }\end{array}$ & {$[24]$} \\
\hline Chlipala et al. & 2020 & $\begin{array}{l}\text { The Aperio ScanScope } \\
\text { XT imaging system } \\
\text { (Aperio, Vista, CA) } \\
\text { and accompanying } \\
\text { Image-Scope software }\end{array}$ & $\begin{array}{l}\text { The annotated areas were } \\
\text { analyzed using a } \\
\text { modified DAB specific } \\
\text { positive pixel } \\
\text { count algorithm }\end{array}$ & 10 markers & $\begin{array}{l}\text { The image analysis output } \\
\text { correlated well with } \\
\text { pathology scores }\end{array}$ & {$[31]$} \\
\hline Yoo et al. & 2020 & $\begin{array}{l}\text { Slides were subsequently } \\
\text { scanned by an Aperio } \\
\text { AT2 slide scanner } \\
\text { (Leica Biosystems) }\end{array}$ & $\begin{array}{c}\text { An open-source software } \\
\text { [QuPath (https://qupath.github.io)] } \\
\text {-based analytic method } \\
\text { established. Using } \\
\text { a random forest classifier, } \\
\text { TIL numbers were quantified }\end{array}$ & $\mathrm{CD} 3, \mathrm{CD} 8$ & $\begin{array}{c}\text { Machine-learning-based } \\
\text { image analysis can be useful } \\
\text { for extracting quantitative } \\
\text { information about the TIME } \\
\text { using whole-slide } \\
\text { histopathologic images }\end{array}$ & {$[25]$} \\
\hline Miyata et al. & 2021 & $\begin{array}{l}\text { Winroof with digital } \\
\text { camera system } \\
\text { (DP70-SET-B, Olympus) }\end{array}$ & Our own & CD8, PD-1 & $\begin{array}{l}\text { Automatic measurement } \\
\text { of TIL in } 56 \\
\text { hypermutator tumors }\end{array}$ & Ours \\
\hline
\end{tabular}


clinical trials $(1,2,19)$. In addition to the clinical evaluation of responders and adverse effects, methods for making histological evaluations of tumor tissues, namely, the tumor microenvironment, have not been fully developed. In particular, the development of suitable imaging analysis software focusing on TIL enumeration has not yet been successful; thus, manual measurements of TIL numbers after ICB therapy are becoming an increasingly large load to working pathologists. Additionally, high variability among observers and limited reproducibility are inevitable challenges to overcome (20).

Recently, novel imaging analysis systems contributing to automatic IHC evaluation without manual labor by pathologists, such as ImageJ, Fiji, Icy, CellProfiler, QuPath, and deep learning methods, have been studied at a clinical research level in the field of digital pathology (21). In particular, QuPath is a new bioimage analysis software designed to meet the growing need for a user-friendly, extensible, open-source solution for digital pathology and whole slide image analysis. These analysis systems seem to be somewhat expensive to ordinary pathological laboratories in terms of the setup of imaging scanner equipment (22).

In the present study, we established a simple automatic TIL number measurement method based on parameter settings adjusted to manually measured TIL numbers using IHC sections of hypermutator tumors.

First, we focused on the enumeration of $\mathrm{CD} 8^{+}$and $\mathrm{PD}-1^{+}$ $\mathrm{T}$ cells inside tumor tissues. The reason is that the $\mathrm{CD} 8^{+} \mathrm{PD}-$ $1^{+} \mathrm{T}$ cell population is well known as exhausted effector $\mathrm{T}$ cells, and a high accumulation of $\mathrm{CD} 8^{+} \mathrm{PD}-1^{+} \mathrm{T}$ cells inside the tumor is a hallmark of good responders to ICI therapy and good prognosis (23).

Second, we used specific parameter settings suitable for each target protein and tried to adjust the parameter many times to manually measured numbers. We observed that the parameter setting may depend on the different staining patterns of each protein, even for markers expressed on the same T cell, such as CD8 and PD-1. Specifically, the first parameter setting suitable for $\mathrm{CD}^{+} \mathrm{T}$ cell counting did not perform well in $\mathrm{PD}-1^{+} \mathrm{T}$ cell counting, therefore we made an adjustment to the second parameter setting.

Third, we aimed to develop automatic measurements specific to TIL counting. In recent years, the development of imaging analysis algorithms has mainly focused on positivity and intensity determination for cancer-associated biomarkers in IHC specimens. The few studies that were involved in the development of automatic TIL number measurements are shown in Table II (24-31).

Brown et al. reported that image analysis scoring based on a color deconvolution algorithm was highly comparable with pathologist scoring for CTLA-4 and CTLA-4/FoxP3 staining of regulatory T cells (24). Meanwhile, Yoo et al. demonstrated that machine-learning-based image analysis such as QuPath can be useful for extracting quantitative information about the
TMIT (tumor microenvironment immune types) using wholeslide histopathologic images (25).

Regarding the correlation analysis between manual and automatic measurements of TIL numbers, our method is comparable to other methods reported in Table II. Regarding the correlation between automatic and manual counting in $\mathrm{CD}^{+}$TILs, our efficiency by Pearson`s test was 0.738 , while the efficiency in the study by Yoo et al. (25) was 0.657 0.707. These results suggest that a commercially available imaging analysis software-based simple automatic measurement system for TIL numbers can be worthwhile to ameliorate hard manual labor, such as manual TIL counting by pathologists. Additionally, we investigated the association of the automatic or manual count number of $\mathrm{CD}^{+}$and $\mathrm{PD}-1^{+} \mathrm{T}$ cells with the mRNA gene expression levels measured by real-time PCR (Table I). Regarding the TIL numbers in gastric cancers, CD8 gene expression was well-associated with both automatically and manually counted numbers; however, PD-1 gene expression had a higher association with manually counted numbers than with automatically counted numbers. These results suggest that the parameter condition in the automatic measurement of PD- $1^{+}$cells still needs to be improved.

Moreover, beyond IHC imaging analysis, genetic TIL number semiquantitative enumeration based on highly advanced single-T cell RNA sequencing and cy-time-offlight (TOF) mass spectrometry technologies has been developed efficiently $(32,33)$ and can be applicable to TIL status evaluation before and after ICI therapy; however, because of the expensiveness of this professional analysis system, it will take a long time until the RNA-seq system is used at the clinical level.

Finally, based on the successful result of our own automatic TIL measurement, we will apply the automatic method to immunofluorescent CD8 and PD-1-stained specimens beyond IHC specimen analysis. Therefore, we will be able to improve the accuracy and utility by developing a multicolor analysis system on the same specimen.

\section{Conflicts of Interest}

The Authors have no conflicts of interest to declare in relation to this study.

\section{Authors' Contributions}

HM and YA participated in the design of the study and drafting of the manuscript and were responsible for competing the study. AI, $\mathrm{CM}, \mathrm{AK}, \mathrm{KW}$ and TA performed immunological experiments including immunohistochemistry. TN, RK, AN and Keita Mori were responsible for the statistical analysis and reviewed the manuscript. AS and MT participated in collecting clinical specimens and KU and $\mathrm{KO}$ were responsible for genetic analysis of clinical samples. TK, Koji Muramatsu and TS were responsible for preparing pathological specimens for TIL analysis. KY reviewed the manuscript. All Authors read and approved the final draft. 


\section{Acknowledgements}

The Authors would like to thank the staff at the Shizuoka Cancer Center Hospital for their clinical support and sample preparation. This research did not receive any specific grant from funding agencies in the public, commercial, or not-for-profit sectors. This work was supported by the Shizuoka Prefectural Government, Japan.

\section{References}

1 Paz-Ares L, Ciuleanu TE, Cobo M, Schenker M, Zurawski B, Menezes J, Richardet E, Bennouna J, Felip E, Juan-Vidal O, Alexandru A, Sakai H, Lingua A, Salman P, Souquet PJ, De Marchi P, Martin C, Pérol M, Scherpereel A, Lu S, John T, Carbone DP, Meadows-Shropshire S, Agrawal S, Oukessou A, Yan $\mathrm{J}$ and Reck M: First-line nivolumab plus ipilimumab combined with two cycles of chemotherapy in patients with non-small-cell lung cancer (CheckMate 9LA): an international, randomised, openlabel, phase 3 trial. Lancet Oncol 22(2): 198-211, 2021. PMID: 33476593. DOI: 10.1016/S1470-2045(20)30641-0

2 Motzer R, Alekseev B, Rha SY, Porta C, Eto M, Powles T, Grünwald V, Hutson TE, Kopyltsov E, Méndez-Vidal MJ, Kozlov V, Alyasova A, Hong SH, Kapoor A, Alonso Gordoa T, Merchan JR, Winquist E, Maroto P, Goh JC, Kim M, Gurney H, Patel V, Peer A, Procopio G, Takagi T, Melichar B, Rolland F, De Giorgi U, Wong S, Bedke J, Schmidinger M, Dutcus CE, Smith AD, Dutta L, Mody K, Perini RF, Xing D, Choueiri TK and CLEAR Trial Investigators: Lenvatinib plus pembrolizumab or everolimus for advanced renal cell carcinoma. N Engl J Med 384(14): 12891300, 2021. PMID: 33616314. DOI: 10.1056/NEJMoa2035716

3 Ogino S, Nosho K, Irahara N, Meyerhardt JA, Baba Y, Shima K, Glickman JN, Ferrone CR, Mino-Kenudson M, Tanaka N, Dranoff G, Giovannucci EL and Fuchs CS: Lymphocytic reaction to colorectal cancer is associated with longer survival, independent of lymph node count, microsatellite instability, and $\mathrm{CpG}$ island methylator phenotype. Clin Cancer Res 15(20): 6412-6420, 2009. PMID: 19825961. DOI: 10.1158/10780432.CCR-09-1438

4 Huijbers A, Tollenaar RA, v Pelt GW, Zeestraten EC, Dutton S, McConkey CC, Domingo E, Smit VT, Midgley R, Warren BF, Johnstone EC, Kerr DJ and Mesker WE: The proportion of tumorstroma as a strong prognosticator for stage II and III colon cancer patients: validation in the VICTOR trial. Ann Oncol 24(1): 179185, 2013. PMID: 22865778. DOI: 10.1093/annonc/mds246

5 Hendry S, Salgado R, Gevaert T, Russell PA, John T, Thapa B, Christie M, van de Vijver K, Estrada MV, Gonzalez-Ericsson PI, Sanders M, Solomon B, Solinas C, Van den Eynden GGGM, Allory Y, Preusser M, Hainfellner J, Pruneri G, Vingiani A, Demaria S, Symmans F, Nuciforo P, Comerma L, Thompson EA, Lakhani S, Kim SR, Schnitt S, Colpaert C, Sotiriou C, Scherer SJ, Ignatiadis M, Badve S, Pierce RH, Viale G, Sirtaine N, Penault-Llorca F, Sugie T, Fineberg S, Paik S, Srinivasan A, Richardson A, Wang Y, Chmielik E, Brock J, Johnson DB, Balko J, Wienert S, Bossuyt V, Michiels S, Ternes N, Burchardi N, Luen SJ, Savas P, Klauschen F, Watson PH, Nelson BH, Criscitiello C, O'Toole S, Larsimont D, de Wind R, Curigliano G, André F, Lacroix-Triki M, van de Vijver M, Rojo F, Floris G, Bedri S, Sparano J, Rimm D, Nielsen T, Kos Z, Hewitt S, Singh B, Farshid G, Loibl S, Allison KH, Tung N, Adams S, Willard-Gallo K, Horlings HM, Gandhi L, Moreira A, Hirsch F, Dieci MV, Urbanowicz M, Brcic I, Korski K, Gaire F, Koeppen H,
Lo A, Giltnane J, Rebelatto MC, Steele KE, Zha J, Emancipator K, Juco JW, Denkert C, Reis-Filho J, Loi S and Fox SB: Assessing tumor-infiltrating lymphocytes in solid tumors: A practical review for pathologists and proposal for a standardized method from the International Immunooncology Biomarkers Working Group: Part 1: Assessing the host immune response, TILs in invasive breast carcinoma and ductal carcinoma in situ, metastatic tumor deposits and areas for further research. Adv Anat Pathol 24(5): 235-251, 2017. PMID: 28777142. DOI: 10.1097/PAP.0000000000000162

6 Pagès F, Mlecnik B, Marliot F, Bindea G, Ou FS, Bifulco C, Lugli A, Zlobec I, Rau TT, Berger MD, Nagtegaal ID, VinkBörger E, Hartmann A, Geppert C, Kolwelter J, Merkel S, Grützmann R, Van den Eynde M, Jouret-Mourin A, Kartheuser A, Léonard D, Remue C, Wang JY, Bavi P, Roehrl MHA, Ohashi PS, Nguyen LT, Han S, MacGregor HL, Hafezi-Bakhtiari S, Wouters BG, Masucci GV, Andersson EK, Zavadova E, Vocka M, Spacek J, Petruzelka L, Konopasek B, Dundr P, Skalova H, Nemejcova K, Botti G, Tatangelo F, Delrio P, Ciliberto G, Maio M, Laghi L, Grizzi F, Fredriksen T, Buttard B, Angelova M, Vasaturo A, Maby P, Church SE, Angell HK, Lafontaine L, Bruni D, El Sissy C, Haicheur N, Kirilovsky A, Berger A, Lagorce C, Meyers JP, Paustian C, Feng Z, Ballesteros-Merino C, Dijkstra J, van de Water C, van Lent-van Vliet S, Knijn N, Muşină AM, Scripcariu DV, Popivanova B, Xu M, Fujita T, Hazama S, Suzuki N, Nagano H, Okuno K, Torigoe T, Sato N, Furuhata T, Takemasa I, Itoh K, Patel PS, Vora HH, Shah B, Patel JB, Rajvik KN, Pandya SJ, Shukla SN, Wang Y, Zhang G, Kawakami Y, Marincola FM, Ascierto PA, Sargent DJ, Fox BA and Galon $\mathrm{J}$ : International validation of the consensus Immunoscore for the classification of colon cancer: a prognostic and accuracy study. Lancet 391(10135): 2128-2139, 2018. PMID: 29754777. DOI: 10.1016/S0140-6736(18)30789-X

7 Schneider CA, Rasband WS and Eliceiri KW: NIH Image to ImageJ: 25 years of image analysis. Nat Methods 9(7): 671-675, 2012. PMID: 22930834. DOI: 10.1038/nmeth.2089

8 Schindelin J, Arganda-Carreras I, Frise E, Kaynig V, Longair M, Pietzsch T, Preibisch S, Rueden C, Saalfeld S, Schmid B, Tinevez JY, White DJ, Hartenstein V, Eliceiri K, Tomancak P and Cardona A: Fiji: an open-source platform for biologicalimage analysis. Nat Methods 9(7): 676-682, 2012. PMID: 22743772. DOI: $10.1038 /$ nmeth.2019

9 de Chaumont F, Dallongeville S, Chenouard N, Hervé N, Pop S, Provoost T, Meas-Yedid V, Pankajakshan P, Lecomte T, Le Montagner Y, Lagache T, Dufour A and Olivo-Marin JC: Icy: an open bioimage informatics platform for extended reproducible research. Nat Methods 9(7): 690-696, 2012. PMID: 22743774. DOI: $10.1038 /$ nmeth.2075

10 Lamprecht MR, Sabatini DM and Carpenter AE: CellProfiler: free, versatile software for automated biological image analysis. Biotechniques 42(1): 71-75, 2007. PMID: 17269487. DOI: 10.2144/000112257

11 Bankhead P, Loughrey MB, Fernández JA, Dombrowski Y, McArt DG, Dunne PD, McQuaid S, Gray RT, Murray LJ, Coleman HG, James JA, Salto-Tellez M and Hamilton PW: QuPath: Open source software for digital pathology image analysis. Sci Rep 7(1): 16878, 2017. PMID: 29203879. DOI: 10.1038/s41598-017-17204-5

12 Bankhead P, Fernández JA, McArt DG, Boyle DP, Li G, Loughrey MB, Irwin GW, Harkin DP, James JA, McQuaid S, Salto-Tellez M and Hamilton PW: Integrated tumor identification and automated 
scoring minimizes pathologist involvement and provides new insights to key biomarkers in breast cancer. Lab Invest 98(1): 1526, 2018. PMID: 29251737. DOI: 10.1038/labinvest.2017.131

13 Gavrielides MA, Gallas BD, Lenz P, Badano A and Hewitt SM: Observer variability in the interpretation of HER $2 /$ neu immunohistochemical expression with unaided and computeraided digital microscopy. Arch Pathol Lab Med 135(2): 233-242, 2011. PMID: 21284444. DOI: $10.5858 / 135.2 .233$

14 Dahlin AM, Henriksson ML, Van Guelpen B, Stenling R, Oberg $\mathrm{A}$, Rutegård $\mathrm{J}$ and Palmqvist R: Colorectal cancer prognosis depends on T-cell infiltration and molecular characteristics of the tumor. Mod Pathol 24(5): 671-682, 2011. PMID: 21240258. DOI: $10.1038 /$ modpathol.2010.234

15 Ashizawa T, Iizuka A, Nonomura C, Kondou R, Maeda C, Miyata H, Sugino T, Mitsuya K, Hayashi N, Nakasu Y, Maruyama K, Yamaguchi K, Katano I, Ito M and Akiyama Y: Antitumor effect of programmed death-1 (PD-1) blockade in humanized the NOGMHC double knockout mouse. Clin Cancer Res 23(1): 149-158, 2017. PMID: 27458246. DOI: 10.1158/1078-0432.CCR-16-0122

16 Joblove $G$ and Greenberg D: Color spaces for computer graphics. ACM SIGGRAPH Computer Graphics 12(3): 20-25, 2021. DOI: $10.1145 / 965139.807362$

17 Mason SA, White IM, Lalondrelle S, Bamber JC and Harris EJ: The stacked-ellipse algorithm: An ultrasound-based 3-D uterine segmentation tool for enabling adaptive radiotherapy for uterine cervix cancer. Ultrasound Med Biol 46(4): 1040-1052, 2020. PMID: 31926750. DOI: 10.1016/j.ultrasmedbio.2019.09.001

18 Kanda Y: Investigation of the freely available easy-to-use software 'EZR' for medical statistics. Bone Marrow Transplant 48(3): 452-458, 2013. PMID: 23208313. DOI: 10.1038/bmt. 2012.244

19 Bergholz JS, Wang Q, Kabraji S and Zhao JJ: Integrating immunotherapy and targeted therapy in cancer treatment: Mechanistic insights and clinical implications. Clin Cancer Res 26(21): 5557-5566, 2020. PMID: 32576627. DOI: 10.1158/ 1078-0432.CCR-19-2300

20 Girolami I, Parwani A, Barresi V, Marletta S, Ammendola S, Stefanizzi L, Novelli L, Capitanio A, Brunelli M, Pantanowitz $\mathrm{L}$ and Eccher A: The landscape of digital pathology in transplantation: From the beginning to the virtual E-slide. J Pathol Inform 10: 21, 2019. PMID: 31367473. DOI: 10.4103/jpi.jpi_27_19

21 Higgins C: Applications and challenges of digital pathology and whole slide imaging. Biotech Histochem 90(5): 341-347, 2015. PMID: 25978139. DOI: 10.3109/10520295.2015.1044566

22 Humphries MP, Maxwell P and Salto-Tellez M: QuPath: The global impact of an open source digital pathology system. Comput Struct Biotechnol J 19: 852-859, 2021. PMID: 33598100. DOI: 10.1016/j.csbj.2021.01.022

23 Kumagai S, Togashi Y, Kamada T, Sugiyama E, Nishinakamura H, Takeuchi Y, Vitaly K, Itahashi K, Maeda Y, Matsui S, Shibahara T, Yamashita Y, Irie T, Tsuge A, Fukuoka S, Kawazoe A, Udagawa H, Kirita K, Aokage K, Ishii G, Kuwata T, Nakama K, Kawazu M, Ueno T, Yamazaki N, Goto K, Tsuboi M, Mano H, Doi T, Shitara $\mathrm{K}$ and Nishikawa $\mathrm{H}$ : The PD-1 expression balance between effector and regulatory $\mathrm{T}$ cells predicts the clinical efficacy of PD1 blockade therapies. Nat Immunol 21(11): 1346-1358, 2020. PMID: 32868929. DOI: 10.1038/s41590-020-0769-3

24 Brown C, Sekhavati F, Cardenes R, Windmueller C, Dacosta K, Rodriguez-Canales $\mathrm{J}$ and Steele KE: CTLA-4 immunohisto- chemistry and quantitative image analysis for profiling of human cancers. J Histochem Cytochem 67(12): 901-918, 2019. PMID: 31609157. DOI: 10.1369/0022155419882292

25 Yoo SY, Park HE, Kim JH, Wen X, Jeong S, Cho NY, Gwon HG, Kim K, Lee HS, Jeong SY, Park KJ, Han SW, Kim TY, Bae JM and Kang GH: Whole-slide image analysis reveals quantitative landscape of tumor-immune microenvironment in colorectal cancers. Clin Cancer Res 26(4): 870-881, 2020. PMID: 31757879. DOI: 10.1158/1078-0432.CCR-19-1159

26 Varghese F, Bukhari AB, Malhotra R and De A: IHC Profiler: an open source plugin for the quantitative evaluation and automated scoring of immunohistochemistry images of human tissue samples. PLoS One 9(5): e96801, 2014. PMID: 24802416. DOI: 10.1371/journal.pone.0096801

27 Wanram S, Sombatwong J, Sakunpong A, Prasongdee P, Panomket P, Wongsena P, Limpaiboon T and Jearanaikoon P: Comparison of automated and conventional IHC visual scoring analysis for MHC class I and tapasin expression in cervical carcinoma. J Med Assoc Thai 99(Suppl 1): S67-S75, 2016. PMID: 26817241.

28 Mane DR, Kale AD and Belaldavar C: Validation of immunoexpression of tenascin- $\mathrm{C}$ in oral precancerous and cancerous tissues using ImageJ analysis with novel immunohistochemistry profiler plugin: An immunohistochemical quantitative analysis. J Oral Maxillofac Pathol 21(2): 211-217, 2017. PMID: 28932029. DOI: 10.4103/jomfp.JOMFP_234_16

29 Fernández-Carrobles MM, Bueno G, García-Rojo M, GonzálezLópez L, López C and Déniz O: Automatic quantification of IHC stain in breast TMA using colour analysis. Comput Med Imaging Graph 61: 14-27, 2017. PMID: 28648530. DOI: 10.1016/j.compmedimag.2017.06.002

30 Tewary S, Arun I, Ahmed R, Chatterjee S and Chakraborty C: AutoIHC-scoring: a machine learning framework for automated Allred scoring of molecular expression in ER- and PR-stained breast cancer tissue. J Microsc 268(2): 172-185, 2017. PMID: 28613390. DOI: $10.1111 /$ jmi.12596

31 Chlipala EA, Bendzinski CM, Dorner C, Sartan R, Copeland K, Pearce R, Doherty F and Bolon B: An image analysis solution for quantification and determination of immunohistochemistry staining reproducibility. Appl Immunohistochem Mol Morphol 28(6): 428436, 2020. PMID: 31082827. DOI: 10.1097/PAI.000000000 0000776

32 Guo X, Zhang Y, Zheng L, Zheng C, Song J, Zhang Q, Kang B, Liu Z, Jin L, Xing R, Gao R, Zhang L, Dong M, Hu X, Ren X, Kirchhoff D, Roider HG, Yan $\mathrm{T}$ and Zhang Z: Global characterization of $\mathrm{T}$ cells in non-small-cell lung cancer by single-cell sequencing. Nat Med 24(7): 978-985, 2018. PMID: 29942094. DOI: 10.1038/s41591-018-0045-3

33 Yost KE, Satpathy AT, Wells DK, Qi Y, Wang C, Kageyama R, McNamara KL, Granja JM, Sarin KY, Brown RA, Gupta RK, Curtis C, Bucktrout SL, Davis MM, Chang ALS and Chang HY: Clonal replacement of tumor-specific T cells following PD-1 blockade. Nat Med 25(8): 1251-1259, 2019. PMID: 31359002. DOI: $10.1038 / \mathrm{s} 41591-019-0522-3$

Received October 29, 2021

Revised November 19, 2021 Accepted November 22, 2021 